VLADIMÍR SZÉKELY

Slovak Academy of Sciences, Bratislava, Slovakia

\title{
Tourism Cluster and Tourism Destination: Liptov Region, Slovakia
}

\begin{abstract}
In connection with development of tourism areas, some studies based on the concept of clusters appear. The term "cluster" is used in scientific literature to denote a strong tendency for networking of economic activities and for their spatial concentration. Networks and active participation of individual players (municipalities, firms, etc.) of these networks are the core features of clusters. Network relationships are particularly important for the sector of tourism, where groups of organizations try to cluster together so as to cooperate and form a tourism destination.

The aim of the paper is to present interconnection between (tourism) cluster as a theoretical concept and the Liptov region as a tourism destination. The first attempt of Slovak tourism cluster establishment in the region of Liptov is shortly introduced and assessed by describing the crucial players (with their "philosophy" of mass tourism production and consumption). The second part of the paper is connected with statistical evaluation of the development of the regional tourism under the influence of the Cluster Liptov.
\end{abstract}

Key words: Fordist mass tourism; Liptov; Slovakia; tourism cluster; tourism destination

\section{INTRODUCTION}

Slovakia, a small country with an attractive landscape, cultural and historic landmarks is not precisely one of those frequently visited. Results of many analyses point to a comparatively low proportion of tourism in the GDP (less than 3\%), which is also attributable to the low proceeds derived from the total number of tourists and an acceptable price of accommodation and catering services provided. Increased proceeds can be reached by an increased number of tourists and/or by expansion of new services and qualitative growth of services provided with an adequate price rise. However, the tourism industry is characterized not only by strong competition between individual countries, regions and localities but also by a high risk rate caused by various factors of natural, economic and even political nature. The fight for clients are won by localities which, apart from possessing natural attractiveness, permanently promote their assets by campaigns supported by the state government or private capital, are easily accessible (Więckowski M. et al., 2012a) and are also capable of offering better 
quality services than their competitors. At the same time, localities successful in terms of numbers of tourists are also noteworthy for high flexibility in addressing the emerging risks.

Governments try to participate in various ways (e.g. legislation, building of transport infrastructure, direct support to investors) in the development of tourism for its significance for the employment, reduction of regional disparities, and for its (potentially) important contribution to the national economic performance. They initiate cooperation between local authorities and entrepreneurs with the aim to form economically efficient groups in tourism (known as Destination Management Organizations) characterizes by the common approach to their promotion. The main aim of this article is to present the history of origins of the first Destination Management Organization (Tourism Cluster Liptov) in the context of broadly viewed economic and spatial development based on the concept of clusters. Organization "Cluster Liptov" (Liptov is the name of historic Slovak region) is a result of agreement between crucial public and private players who decided to cooperate with an aim to increase the visiting rate of the region and to achieve the individual success of common prosperity. The second part of the paper is connected with statistical evaluation of the development of the regional tourism under the influence of Cluster Liptov and confrontation of the current state with original plans.

\section{BRIEF DESCRIPTION OF (TOURISM) CLUSTER CONCEPT}

The term "cluster" was introduced by an American economist M. Porter who described it not only as an analytical concept but also as a political tool for achieving the competitiveness of various economical branches (particularly in manufacturing) and spatial units. Porter defines clusters as "geographic concentrations of interconnected companies, specialized suppliers, service providers, firms in related industries, and associated institutions (universities, standards agencies, and trade associations) in particular fields that compete but also cooperate" (Porter 1998). Contracting supply-demand relationships, joint technologies, common purchasers or distribution channels or even the common labour market are the factors that unite a cluster into one unit. But it can also be various training or research initiatives, joint marketing and lobbying (Nordin 2003).

Porter saw a cluster (and clustering) as a geographically localized grouping of interlinked businesses and as one of the possibilities to increase their competitiveness, to improve productivity, and to increase the economic well-being of population living in the area. Although Porter's work is mainly focused on the manufacturing industry, it has also been extended and applied to the service industries, such as tourism.

In his first work devoted to the national competitive advantages and international competitiveness, Porter (1990) develops the idea that the success of exporting companies in a country (competitiveness of firms is associated with their success in the field of export) depends on the "competition diamond". Smeral (1998) used Porter's diamond as a model, facilitating description of the competitive advantages of a tourism destination. He asserts 
that the competitive position of a tourist destination could be explained through four sets of factors: "the factor conditions, the quality and structure of suppliers forming the destination, as well as the operating network alliances and the related experiences, the market and organizational structures, the distribution channels, the strategies and targets; as well as the demand conditions" (Smeral, 1998). He also mentions two additional variables (chance and government), which can influence the economic performance of a destination (Fig. 1). Factor conditions, as a decisive element of tourism success of the Liptov region, have been described by Székely (2010).

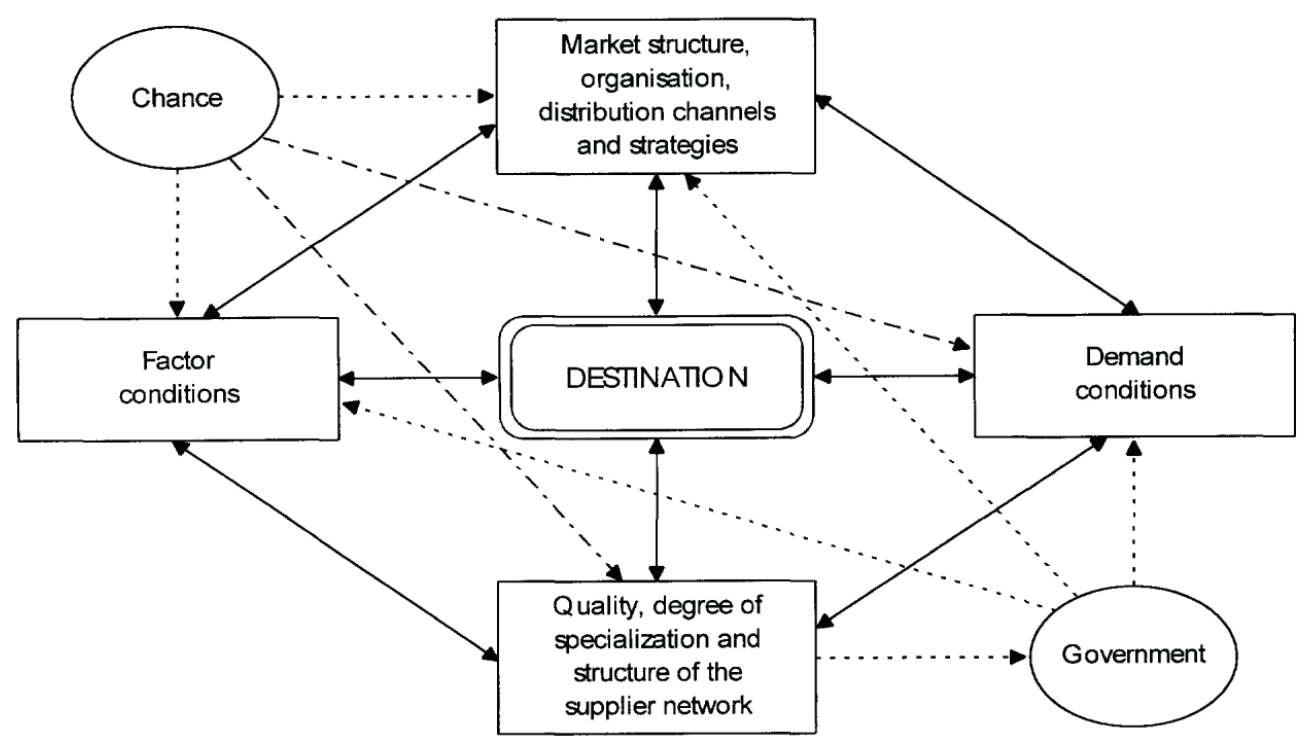

Fig. 1. Competitive advantages of tourism destinations (Smeral, 1998)

Tourism cluster is represented by groups of organizations trying cluster together to form a destination context (Novelli, Schmitz, Spencer 2006). The existence of various networks and active participation of the individual players (municipalities, firms, etc.) are very important for the successfully functioning of a cluster. Typical for tourism (but not only), a cluster is the co-location of complementary firms, which may not necessarily be involved in the same sector, but may benefit by the pre-existing network membership and alliances' dynamics. Networks of created and functional clusters provide access to knowledge, resources, markets, or technologies for individual firms. They also make it possible for actors to participate in the co-development of tourism products or services and spillover of theoretical and practical knowledge: one member of the network (cluster) is affected by the experience of another.

The aim of the tourism cluster is to make use of endogenous territorial potential based not only on the natural potential (a locality's character and relative geographic position) but also on the capabilities of local population (human and social capital), as well as presence 
and quality of locally based supporting industries related to tourism (accommodation and catering facilities, transport service, etc.).

\section{Genesis, Aim, AND FUnCtioning of "Clunter Liptov" - THE FIRST TOURISM CLUSTER IN SLOVAKIA}

The emphasis on competitiveness, prosperity and sustainable development of the member countries and their regions declared by the EU has led the representatives of the Žilina's regional self-administration (with co-operation with local University and partner's institutions) in 2005 to work on the project Innovation Policy of Žilina (part of the Regional Innovation Strategy for the Region of Žilina). Its aim was to create an environment stimulating regional innovation potential, cooperation between the existing institutions and organizations, and to prepare a developmental frame in order to activate the companies so that they introduce further innovations. One of the projects supporting the building of innovation infrastructure (as a part of RIS) was the project Clusters and Partnerships (Dado et al., 2006). Implementation of this project is expected to support not only the cooperation of companies but also to increase their international competitiveness. The real result of the quoted activities was the introduction of the first tourism cluster not only in the region of Žilina but also in Slovakia in general (see Więckowski et al., 2012b). In April 2008, the organization of "Liptov cluster - tourism association" has been established. Its web site (http://www.klasterliptov.sk/) declares that it is "the first Organization of destination management (DMO) in Slovakia and the joint marketing centre of the destination of Liptov".

Liptov, as one of historic regions of Slovakia, is situated in the north of Slovakia and its north-eastern part is in contact with the Slovak-Polish frontier (Fig. 2). It is part of the Administrative region of Žilina. The territory of the Liptov region $\left(1,970 \mathrm{~km}^{2}\right)$ with excellent conditions for development of tourism (Székely, 2010) is not homogeneous - its western part (district of Ružomberok) is a "predominantly rural area" and the eastern part (district of Liptovský Mikuláš) is a "significantly rural or intermediate area" (Székely, 2003). Liptov is not among the most populous regions of Slovakia. According to the last Census of 2011, the population of three towns and 78 rural municipalities amounts to almost 131,000. The biggest town is Liptovský Mikuláš (31,900 inhabitants), which along with Ružomberok (28,400 inhabitants) ranks among the medium-sized towns of Slovakia. Liptovský Hrádok is a smaller town and ranks lower in the settlement hierarchy. Its population amounted 7,600 in time of the recent Census. Over the last decade, the whole region, as well as its three towns, could be classified as depopulating spatial units (according to the official statistical data).

Cluster Liptov associates the entities of the private and public sectors and the aim is the joint promotion of the region of Liptov as the unique "green" region for an "attractive leisure full of agreeable experiences". Founders of the organization with the name containing the word cluster are the three towns of the region (Liptovský Mikuláš, Ružomberok and Liptovský Hrádok) and four important tourism centres with supraregional significance: Aquapark 
Tatralandia, Thermal Park Bě̌eňová, Jasná Nízke Tatry, and Ski Park Ružomberok. In the following years, additional 17 rural municipalities representing the public sector (Smrečany, Trstené, Pavlova Ves, Bobrovec, Bobrovník, Ižipovce, Bešeňová, Podtureň, Pavčina Lehota, Malatiny, Likavka, Liptovský Michal, L’ubel'a, Liptovská Sielnica, Liptovské Sliače, Prosiek, Štiavnička) joined the organization.

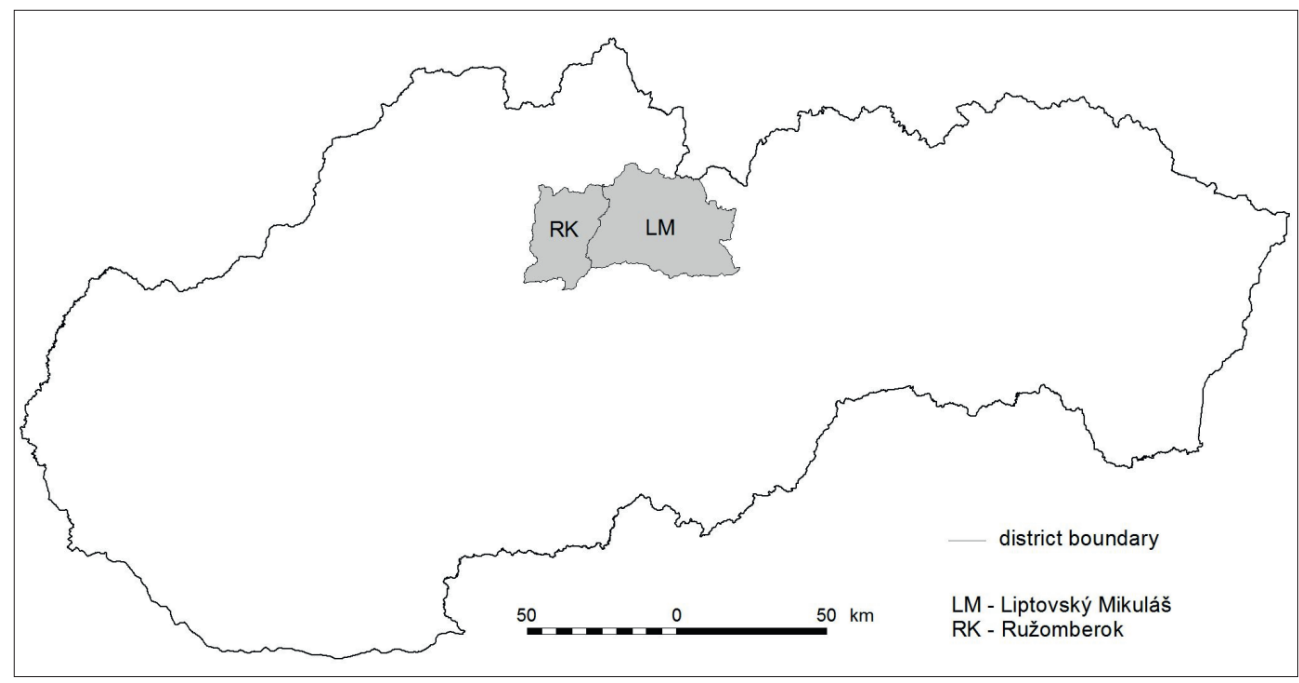

Fig. 2. Geographical position of the region of Liptov in Slovakia

The individual towns, founders of this organization, have been mentioned above. Representatives of the towns appreciate that, in addition to the cultural and historic monuments which they possess, their greatest asset for their visit is the proximity of attractive tourism centres (they are also the founders of the tourism cluster "Liptov") represented by the private business sector (together with towns they constitute an example of an entity similar to public-private partnership) and their activities complement each other. Aquapark Tatralandia, located in the territory administered by Liptovský Mikuláš, with its 14 swimming pools and toboggans is the biggest year-round open water park not only in Slovakia but also in Czech Republic and Poland. It exploits the local thermal springs $\left(60.7^{\circ} \mathrm{C}\right)$, which were the base for building a combination of different services offering a complete physical and mental relaxation of visitors. The Thermal Park Bešeňová was built with the same objective and on the same basis. It is located in an administrative territory of the village situated $12 \mathrm{~km}$ away from Ružomberok. Both companies may as well stand for a typical example of horizontal competitive-cooperative interlinks of the established cluster.

Centres focused on winter sports, Jasná Nízke Tatry and Skipark Ružomberok, represent a considerably less balanced couple. The first of them is located near Liptovský Mikuláš on the territory of several rural municipalities and the National park of Nizke Tatry. It is the most sought out and the biggest winter sport centre in Slovakia. However, the declared ambition of the management is further expansion. There are plans not only to make the centre 
the biggest ski resort in Eastern Europe, but also to diversify activities in order to reach the balanced year-round operation. The result should include an increased visiting rate, proceeds and profit. The centre has been classified into the top category of tourism facilities with international significance. The Skipark Ružomberok has also been included in this category. Its natural potential and the ensuing prospect of spatial expansion though are much more limited than in case of Jasná. However, in spite of being a smaller ski centre, it is among the top-evaluated ski centres in Slovakia. It is situated on the territory administered by the town of Ružomberok (including also some typical rural settlements) and on the territory of the National Park of Vel'ká Fatra. Managers of the centre adopted the same strategy for the future development as those at Jasná: they try to diversify activities in order to reach a more balanced visiting rate during the whole year. Like in the case of regional centres of Liptov exploiting the hot springs, regional ski centres can be also considered entities participating in the horizontal competitive-cooperative interlinks of the established cluster.

The founders and also new public actors financially support the newly established organization as its strategic objective is to double the 2007 visiting rate of Liptov (initial level) up to year 2013 (a typical aim of the Fordism tourism - focus on the quantitative growth). The ambition of the Cluster Liptov is to: "incorporate Liptov to the map of sought-out European tourist destinations, to present Liptov as an unified brand both at home and abroad, to generate competitive products in the sector of tourism, and to promote the active cooperation in the region". Activities of Cluster "Liptov" should be directed to professional coordination of tourism development in the Liptov region.

Establishment of the Cluster Liptov organization supposed to promote the region of Liptov as a tourist destination is linked to the beginnings of a systemic cooperation between the interested public and private stakeholders. Future development of tourism also depends on creation and novelization of legislation rules, the aim of which is to increase the proportion of tourism in the GDP and the overall economic growth. The government can, via legislation, support cluster initiatives which are can be presented under the various terms. A support to regional organizations of tourism (such as the Regional Organization of Tourism Liptov, which in their nature, objectives and functioning are practically analogous to Cluster Liptov) came from the government after the amendment of the Act on Support of Tourism of 2011 (No. 386/2011), which facilitates the exploitation and receipt of the state funds by Regional Organizations of Tourism, while the amount of subsidy depends on the amount of collected member fees of the Organization and the summed up value of the collected accommodation taxes by all (urban and rural) municipality members of the Organizations. Such support is not granted to individual actors of tourism. Practically each of the founding members of the Cluster Liptov (with the exception of the private company Jasná Nízke Tatry) became a member of the Regional Organization of Tourism Region of Liptov. The new members who should contribute to the functioning tourism cluster (also in economic sense of the word) are the rural municipalities Bešeňová and Lúčky. Apart from these representatives of the public sector, the spa Kúpele Lúčky as a private partner active in the segment of wellness centres and aquaparks also joined the cooperation. 


\section{SitUATION IN TOURISM IN THE REGION OF LIPTOV}

Quantitative indicators, the aim of which is to describe the dynamics in the number of tourists and changes in the process of building material-technological basis of tourism (the volume of accommodation facilities) are the tools for measuring tourism development in individual regions. The development is subject to various determinants but the global economic crisis is the factor that affected tourism the most in Slovakia and particularly in the region of Liptov. It seems that a constant economic growth manifesting itself in a continuous increase of number of tourists and their input finances into the regional economy is more or less fictitious. The situation calls for correction, modification, and adaptation to the changed global and local conditions.

An attempt to describe the position of Liptov in the context of the dynamic development of tourism in Slovakia based on the official statistical data provided by the Statistical Office of the SR (http://portal.statistics.sk) follows.

Tab. 1. Changes of tourist importance of Liptov in Administrative Region of Žilina and Slovakia -

Number of accommodation facilities

\begin{tabular}{|l|r|r|r|r|r|r|c|}
\hline & 2002 & 2006 & 2007 & 2008 & 2009 & 2010 & 2011 \\
\hline Slovakia & 2398 & 2490 & 3182 & 3434 & 3292 & 3126 & 3011 \\
\hline $\begin{array}{l}\text { Admistrative Region (AR) } \\
\text { of Žilina }\end{array}$ & 641 & 650 & 872 & 988 & 895 & 826 & 781 \\
\hline District Liptovský Mikuláš & 201 & 172 & 211 & 256 & 238 & 227 & 215 \\
\hline District Ružomberok & 51 & 57 & 79 & 89 & 81 & 73 & 72 \\
\hline Liptov & 252 & 229 & 290 & 345 & 319 & 300 & 287 \\
\hline $\begin{array}{l}\text { Share of Liptov from AR } \\
\text { of Žilina (in \%) }\end{array}$ & 39.31 & 35.23 & 33.26 & 34.92 & 35.64 & 36.32 & 36.75 \\
\hline $\begin{array}{l}\text { Share of Liptov from } \\
\text { Slovakia (in \%) }\end{array}$ & 10.51 & 9.20 & 9.11 & 10.05 & 9.69 & 9.60 & 9.53 \\
\hline
\end{tabular}

Source: Štatistický úrad SR (Statistical Office of the SR)

Compared to 2002, the development in the number of accommodation facilities on the territory of Liptov was less dynamic than in the rest of the Administrative Region of Žilina or in Slovakia as a whole. Table 1 demonstrates that in the following years Liptov was never able to reach a proportion in the market similar to that at the beginning of the $21^{\text {st }}$ century. This very partial statement, however, does not specify the nature of accommodation units or the dramatic decrease of Liptov's significance in tourism of Slovakia. Liptov has maintained its $10 \%$ proportion in accommodation facilities in Slovakia (compared to $2.5 \%$ proportion in total population of Slovakia) and a more than a 33\% proportion in the Administrative Region of Žilina (compared to the $20 \%$ proportion in overall population of the Adm. Region of Žilina). Additional indicators (Tabs. 2 and 3) also confirm the very important Liptov's position in tourism of Slovakia. 
Number of tourist nights spent by visitors in accommodation facilities (Tab. 2) shows that the developmental trends (which are finally the product of dynamic both of macro-economic and microeconomic factors) of Liptov not always coincided with that of Slovakia or the Administrative Region of Žilina. However, an important feature is that of increased proportion in overall volume of tourist nights in accommodation facilities, which means a consolidated dominant position in the Administrative Region and a positive advertisement for the destination of Liptov in the framework of Slovakia. On the other hand, ambitions of managers as far as an increased number of tourism is concerned were far bigger. The numbers do not correspond to the registered growth pace which has been lately observable (2009-2011 by $10.7 \%$ ) following an abrupt decrease in 2008-2009. The dream of the doubled growth presumed for 2007-2013 though, will definitely not come true for the time being. On the other hand, it must be borne in mind that a number of tourists come to Liptov for a day trip without making use of the accommodation offer. Nevertheless, precisely this segment of tourists may contribute to the economic revaluation of the invested means into tourist facilities (ski lifts, aquaparks, etc.).

Tab. 2. Changes of tourist importance of Liptov in Administrative Region of Žilina and Slovakia Number of tourist nights in accommodation facilities

\begin{tabular}{|l|r|r|r|r|r|r|r|}
\hline & 2002 & 2006 & 2007 & \multicolumn{1}{c}{2008} & \multicolumn{1}{c}{2009} & \multicolumn{1}{c}{2010} & 2011 \\
\hline Slovakia & 12306192 & 11137565 & 11566632 & 12464104 & 10391069 & 10367330 & 10524738 \\
\hline $\begin{array}{l}\text { Admistrative } \\
\text { Region (AR) } \\
\text { of Žilina }\end{array}$ & 2159791 & 2255610 & 2358745 & 2535960 & 2106609 & 2135892 & 2227731 \\
\hline $\begin{array}{l}\text { District } \\
\text { Liptovský } \\
\text { Mikulás }\end{array}$ & 836710 & 977546 & 970225 & 1020123 & 804642 & 846080 & 919902 \\
\hline $\begin{array}{l}\text { District } \\
\text { Ružomberok }\end{array}$ & 230499 & 224911 & 267089 & 297207 & 280278 & 270543 & 280989 \\
\hline Liptov & 1067209 & 1202457 & 1237314 & 1317330 & 1084920 & 1116623 & 1200891 \\
\hline $\begin{array}{l}\text { Share of } \\
\text { Liptov from } \\
\text { AR of Žilina } \\
\text { (in \%) }\end{array}$ & 49.41 & 53.31 & 52.46 & 51.95 & 51.50 & 52.28 & 53.91 \\
\hline $\begin{array}{l}\text { Share of } \\
\text { Liptov from } \\
\text { Slovakia } \\
\text { (in \%) }\end{array}$ & 8.67 & 10.80 & 10.70 & 10.57 & 10.44 & 10.77 & 11.41 \\
\hline
\end{tabular}

Source: Štatistický úrad SR (Statistical Office of the SR)

As far as the number of visitors is concerned, although in 2011 it was lower in entire country than in 2007, an increase by $6.7 \%$ was recorded in Liptov (Tab. 3). It contributed to the strengthening of Liptov's position as one of top tourist regions in Slovakia. In the last 10 years the share of Liptov was never so pronounced as it is now. The majority of visitors come from Slovakia (60\%), those from the Czech Republic and Poland prevail among foreigners. Accommodated visitors concentrate in Liptovský Mikuláš, Demänovská Dolina, 
Liptovský Hrádok, Ružomberok, and Bešeňová, i.e. in areas proper to the founding members of Cluster Liptov. It is very difficult to estimate the effects of various marketing and promotional events, which are the main activities of Cluster Liptov. However, the traditional inertia in the behaviour of individual clients who come to verified localities and regions (typical for the Slovak tourism consumers) and investment activities pursued by various business groups expanding the options for satisfaction of tourists also play their role in the official quantitative growth of the number of Liptov visitors.

Tab. 3. Changes of tourist importance of Liptov in Administrative Region of Žilina and Slovakia Number of visitors in accommodation facilities

\begin{tabular}{|l|c|c|c|c|c|c|c|}
\hline & 2002 & 2006 & 2007 & 2008 & 2009 & 2010 & 2011 \\
\hline Slovakia & 3446442 & 3583879 & 3777754 & 4082645 & 3381354 & 3392361 & 3571093 \\
\hline $\begin{array}{l}\text { Admistrative } \\
\text { Region (AR) } \\
\text { of Žilina }\end{array}$ & 596971 & 652770 & 689531 & 767274 & 643290 & 658148 & 717041 \\
\hline $\begin{array}{l}\text { District } \\
\text { Liptovský } \\
\text { Mikulás }\end{array}$ & 232582 & 281498 & 278588 & 300581 & 238724 & 252671 & 294035 \\
\hline $\begin{array}{l}\text { District } \\
\text { Ružomberok }\end{array}$ & 44707 & 54801 & 70005 & 80253 & 77684 & 73293 & 78002 \\
\hline Liptov & 277289 & 336299 & 348593 & 380834 & 316408 & 325964 & 372037 \\
\hline $\begin{array}{l}\text { Share of } \\
\text { Liptov from } \\
\text { AR of Žilina } \\
\text { (in \%) }\end{array}$ & 46.45 & 51.52 & 50.56 & 49.63 & 49.19 & 49.53 & 51.89 \\
\hline $\begin{array}{l}\text { Share of } \\
\text { Liptov from } \\
\text { Slovakia } \\
\text { (in \%) }\end{array}$ & 8.05 & 9.38 & 9.23 & 9.33 & 9.36 & 9.61 & 10.42 \\
\hline
\end{tabular}

Source: Štatistický úrad SR (Statistical Office of the SR)

\section{FORDIST MASS TOURISM AND ITS CHARACTERISTICS}

All official documents mentioning the aim of the Cluster Liptov concentrate on the quantitative increase of tourists. Ways to reach such an increase are mostly extensive and therefore they can be referred to (on the basis of scientific literature) as "Fordist tourism" and/or "mass tourism".

Fordist tourism is associated with specific mass production characteristics (Torres 2002). Mass tourism is characterized by a small number of producers with power and control, and therefore this segment of tourist market is more important than consumers. Mass production is connected with economies of scale. For a financial success it is necessary to attract a great amount of relatively solvent visitors (middle class clients). Another typical characteristic of Fordist tourism is its spatial (the most attractive places) and temporal (seasonal 
factor) concentration with a negative impact on the environment. Products of mass tourism are often standardized and also the group of clients has the same or a very similar idea how to spend the recreation time. We are speaking about undifferentiated clientele with collective consumption. Fordist mass tourism is represented not only as a system of production, but also as a mode of consumption embedded in the wider context of social relations (Torres 2002). Typical consumption is characterized by the large-scale, homogenized and standardized production which offers "highly predictable, standard, efficient, calculable and controlled vacations («McDisneyfication»)". The overview of several production and consumption-related characteristics associated with Fordist mass tourism and their comparison with characteristics of post-Fordist tourism and neo-Fordist tourism is presented in summarizing Tab. 4 (Torres 2002).

Tab. 4. Fordist spectrum of tourist production and consumption (Torres 2002)

\begin{tabular}{|l|l|l|}
\hline $\begin{array}{l}\text { Fordist tourism } \\
\text { Mass Tourism }\end{array}$ & $\begin{array}{l}\text { Post-Fordist tourism } \\
\text { Specialized/Individualized/ } \\
\text { Customized Niche Market Tourism }\end{array}$ & $\begin{array}{l}\text { Neo-Fordist tourism } \\
\text { Niche Market Mass Tourism }\end{array}$ \\
\hline $\begin{array}{l}\text { Inflexible/Rigidity } \\
\text { Spatially Concentrated } \\
\text { Undifferentiated Products } \\
\text { Small Number of Producers }\end{array}$ & $\begin{array}{l}\text { Flexibility } \\
\text { Shorter Product Life Cycle } \\
\text { Product Differentiation }\end{array}$ & $\begin{array}{l}\text { Product Differentiation } \\
\text { Continuity of Fordist } \\
\text { Structures/Institutions }\end{array}$ \\
\hline $\begin{array}{l}\text { Discounted Product } \\
\text { Economies of Scale } \\
\text { Large Number of Consumers } \\
\text { Collective Consumption } \\
\text { Undifferentiated Consumers } \\
\text { Seasonally Polarized }\end{array}$ & $\begin{array}{l}\text { Small Scale or "Small Batch" } \\
\text { Consumer Controlled } \\
\text { Individualized Consumption } \\
\text { "Better Tourists" }\end{array}$ & $\begin{array}{l}\text { Mass Customization } \\
\text { Consumer Choice }\end{array}$ \\
$\begin{array}{l}\text { Demand Western Amenities } \\
\text { Staged Authenticity }\end{array}$ & $\begin{array}{l}\text { Rapidly Changing Consumer Tastes } \\
\text { Desire Authenticity }\end{array}$ & $\begin{array}{l}\text { Desire Reality While } \\
\text { Reveling in Kitsch }\end{array}$ \\
\hline $\begin{array}{l}\text { Environmental Pressures } \\
\text { "McDonaldization" } \\
\text { or "Disneyfication" }\end{array}$ & $\begin{array}{l}\text { "Green Tourism" } \\
\text { "De-McDonaldization" }\end{array}$ & "McDonalized" Product \\
\hline
\end{tabular}

The current tourism industry in Slovakia (and in the Liptov region) acquired the form of mass tourism with Fordist production and consumption. All private partners of the Cluster Liptov with their entrepreneurial activities (ski resorts and aquaparks with their products) can be characterized as representatives of predominately Fordist mass tourism with the cardinal aim - to increase the number of tourists consuming highly standardized, packaged and inflexible tourism products. Increase of number of tourists automatically means the increase of their financial profit. The very close cooperation with public local governments with preferred ideology of extensive socio-economic development contributes to the creation of Liptov as a mass tourism destination. 
The owner of the ski resort in Jasná (the Chopok Mt. north) with the total length of ski tracks of more than $26 \mathrm{~km}$ and transport capacity of almost 20,000 skiers/hour is the Tatry Mountain Resorts, joint stock company - a developer seated in Liptovský Mikuláš which is the biggest tourist company in Slovakia. Its entrepreneurial activities are concentrated in the Nízke Tatry Mts. and Vysoké Tatry Mts. In the cadastral territory of Liptov, the company also owns Tatralandia, the biggest water park in Central Europe with 14 swimming pools, as well as a network of cooperating accommodating, shopping and catering businesses. The character and philosophy of entrepreneurial activities of Tatry Mountain Resorts (with a great emphasis on expansion to Czech and Polish markets) are determined by close links to an important financial group (J\&T). Investments of the Company practically covering all relevant segments of tourism (transport infrastructure and transport facilities, expansion of Tatralandia aquapark adding to it a Tropical Paradise, construction of accommodation facilities, etc.) are not only extraordinarily large but also controversial in terms of environmental protection. Activities of the company which declares its focus on an affluent clientele (especially in the case of property market) from Central and Eastern Europe (Slovak Republic, Czech Republic, Poland) runs into protests not only on the part of environmentally involved scientific community but also on the part of public at large. The thing is that spatial concentration of visitors increases in the most attractive spots and the well-to-do visitors seek out unconventional events often associated with the negative environmental impact (noisy discotheques in the National Park of Nízke Tatry Mts. or horses polo matches on the ice-covered Štrbské pleso Lake in the Vysoké Tatry Mts.). Media often confront intentions of the private company, which besides concentration on own profit and increased company competitiveness also contributes to creation of jobs and economic development of the regions, with a global interests of the society and the sustainability idea especially on the territory under the top level nature protection (National Parks).

\section{Conclusion}

The ideas of cooperation between regional actors that might bring benefits to all and each of them are not new. It is rather the emphasis put on the confidence and openness that is new and necessary for the innovative solutions in the current politically and economically faltering environment. Likewise, the support to cluster initiatives available from the EU or the government is new. The assistance is in place also in terms of searching for new options of addressing the problems connected with the global economic and dept crisis. Options of assistance to economic entities and geographical units are sought because many of them stagnate or face a crash. Peripheral rural regions that lost their human potential are the most threatened ones. Experience shows that building successful regions via cluster initiatives has some prerequisites that secure certain prosperity in a particular developmental stage. A turn in comparative and competitive advantages may also cause successful regions to become less successful or even failures. 
Liptov now is a top tourist Slovak destination presented by media as the one possessing a high growth potential. The population of Slovakia perceives Liptov above all as a region with a extra high natural and landscape value (National Parks, folk architecture and conserved folk traditions). However, there is a real danger that the development of mass tourism may degrade the natural and landscape potential of the region with simultaneous reduction of its tourist attraction. The partial initial negative impulse could be then accompanied by very negative impact on the complex socio-economic development of the region. Fortunately, such a catastrophic scenario, which currently acts as a kind of memento, is very unlikely to accept conditio sine qua non: the transfer of knowledge and rational application of "good practices" of landscape management from long-term successful tourist regions.

Translated by H. Contrerasová

\section{Acknowledgements}

This article was prepared as part of the Project No. 2/0086/12 "Endogenous potential and exogenous factors of local and regional development in Slovakia", funded by the Slovak VEGA Grant Agency. The author thanks to the Slovak VEGA Grant Agency for its financial support.

\section{References}

Dado, M. et al. (2006). Rámcová stratégia Žilinského regiónu pre oblast' inovačného rozvoja. Žilinská univerzita, Žilina (http://www.zip.utc.sk).

Klaster Liptov - 1. slovenská organizácia destinačného manažmentu (DMO) (http://www.klaster liptov.sk).

Nordin, S. (2003). Tourism Clustering and Innovations, no.14, ETOUR Mid-Sweden University, Östersund.

Novelli, M., Schmitz, B., Spencer, T. (2006). Networks, Clusters and Innovation in Tourism: A UK experience. Tourism Management, 27, 1141-1152.

Porter, M. (1990). The Competitive Advantage of Nations, New York: The Free Press.

Porter, M. (1998). On Competition. Harvard Business School Press.

Smeral, E. (1998). The Impact of Globalization on Small and Medium Enterprises: New Challenges for Tourism Policies in European Countries. Tourism Management, 19(4), 371-380.

Székely, V. (2003). Tourism in Rural Areas of Slovakia: Economic Development and/or Sustainable Development? Geopolitical Studies, 11 - Eastern Dimension of European Union, 251-264.

Székely, V. (2010). Tourism Clusters as a Tool for the Improvement of Rural Competitiveness: First Experiences from Slovakia. In: A. Fieldsend (ed.), Rural Areas and Development, 7 - Linking Competitiveness with Equity and Sustainability: New Ideas for the Socio-Economic Development of Rural Areas. Warsaw (European Rural Development Network), 109-120.

Štatistický úrad Slovenskej republiky, Bratislava (http://portal.statistics.sk).

Torres, R. (2002). Cancun's Tourism Development from a Fordist Spectrum of Analysis. Tourist Studies, 2(1), 87-116.

Tatry mountain resorts, a.s., Liptovský Mikuláš (http://www.tmr.sk). 
Więckowski, M., Michniak, D., Bednarek-Szczepańska, M., Chrenka, B., Ira, V., Komornicki, T., Rosik, P., Stępniak, M., Székely, V., Sleszyński, P., Świątek, D., Wiśniewski, R. (2012a). Pol’skoslovenské pohraničie z hladiska dopravnej dostupnosti a rozvoja cestovného ruchu. Varšava - Bratislava: Instytut Geografii i Przestrzennego Zagospodarowania, Polska Akademia Nauk, Geografický ústav Slovenskej akadémie vied.

Więckowski, M., Michniak, D., Chrenka, B., Ira, V., Komornicki, T., Rosik, P., Székely, V., Sleszyński, P., Wiśniewski, R. (2012b). Možnosti zlepšenia dostupnosti a rozvoja cestovného ruchu $v$ pol'sko-slovenskom pohraniči - námety, odporúčania a dobré priklady. Varšava-Bratislava: Instytut Geografii i Przestrzennego Zagospodarowania, Polska Akademia Nauk, Geografický ústav Slovenskej akadémie vied.

Vladimír Székely, CSc., RNDr., Slovak Academy of Sciences, Institute of Geography, Bratislava, Slovakia.

Descriptive biographical note about the author: Vladimír Székely - senior scientific worker in human and regional geography. He received the $\mathrm{PhD}$ title in 1992 after defence of dissertation thesis on industrial geography. Nowadays, he is more interested in the problems of local and regional development with special emphasis put on rural development. Great part of results of his scientific activities has been published in Poland.

adres/address: Slovak Academy of Sciences

Institute of Geography

Štefánikova 49, 814-73 Bratislava, Slovenská republika

e-mail: szekely@savba.sk 